\title{
53. DATA REPORT: GEOCHEMICAL RESULTS FROM WIRELINE LOGS AT SITES 761, 762, AND 7641
}

\author{
Elizabeth Lewis Pratson, ${ }^{2}$ Xenia Golovchenko, ${ }^{2}$ Cristina Broglia ${ }^{2}$
}

\begin{abstract}
Geochemical well logs were obtained at Sites 761, 762, and 764 of Leg 122 on the Exmouth Plateau. The preliminary log measurements which were presented in the Initial Reports have been corrected for borehole size, borehole fluids, and logging speed variations. The corrected logs are used to calculate percentages of the naturally radioactive elements and oxides of the formation. The $\mathrm{CaCO}_{3}$ logs agree well with core-derived carbonate measurements from Holes $762 \mathrm{C}$ and $764 \mathrm{~B}$, and agree less with measurements from Hole $761 \mathrm{C}$. The geochemical logs are found to be useful in refining major lithologic changes in each of the three wells.
\end{abstract}

\section{INTRODUCTION}

Leg 122 was drilled on the Exmouth Plateau, in an old sediment-starved margin off the northwest coast of Australia. The sites on Leg 122 of the Ocean Drilling Program (ODP) were drilled along two transects: Sites 759, 760, 761 and 764 were drilled to study the Triassic to Cenozoic evolution of the Wombat Plateau, a small sub-plateau of the northern Exmouth Plateau; Sites 762 and 763 were drilled to study the Cretaceous to Cenozoic passive-margin evolution of the south-central Exmouth Plateau.

Logging was carried out at all six of the sites drilled. Due to time constraints, however, only three of these sites were logged with the geochemical tool string: Sites 761 and 764 on the Wombat Plateau and Site 762 on the Exmouth Plateau. Geochemical logs provide continuous measurements of all the major rock-forming elements. These measurements are used to derive the weight fraction of the major oxides present in the formation.

This paper will discuss the logging conditions at each of the sites logged with the geochemical tool and review the basic principles and modes of operation of the geochemical tools and the data processing techniques. The results of the postcruise analysis of the geochemical $\log$ data from Sites 761, 762 , and 764 will then be presented along with carbonate core measurements. A brief discussion of how the logs compare to lithologic core descriptions will follow.

\section{DATA ACQUISITION}

To prepare for logging, a wiper trip was made in each of the logged holes. While weather conditions were favorable, borehole instabilities (Site 761) and problems with the hydraulic bit release (Site 764) forced logging through pipe with the geochemical tool. Although electrical and acoustical logs do not work through pipe, nuclear logs can be recorded, as the neutrons from the source and the gamma rays from the formation can penetrate the pipe. The amount of data from the formation gathered by the tool is reduced and the signal-to-noise level decreases. Site 762 , on the other hand, was logged open hole; therefore, $\operatorname{logs}$ at this site provide the most reliable data.

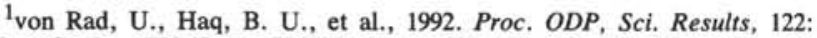
College Station, TX (Ocean Drilling Program).

${ }^{2}$ Lamont-Doherty Geological Observatory of Columbia University, Palisades, NY 10964, U.S.A.
}

In Hole $761 \mathrm{C}$ the seismic-stratigraphic tool string was run open hole. However, a bridge at 260 meters below seafloor (mbsf) prevented logging of the lower portion with this tool string. Because of the bridge formation in this hole, pipe was lowered to the bottom of the well and the geochemical tool string was run through pipe, recording logs from 424 to $58.2 \mathrm{mbsf}$.

In Hole $762 \mathrm{C}$, a complete pass of all three electrical, acoustical, and nuclear tool strings was run in the following order: (1) seismic-stratigraphic tool string, (2) geochemical tool string, and (3) lithodensity tool string. All three logging strings were run successfully in open hole without any problems in the hole.

The hydraulic bit release failed at Hole 764B, preventing any open-hole logging. Two logging passes were completed through pipe-the geochemical logging string and the lithodensity tool string-both from 265 mbsf to $10 \mathrm{~m}$ above the mud line.

\section{GEOCHEMICAL TOOL STRING}

The geochemical logging tool (GLT) string consists of four separate logging tools: the natural gamma ray tool (NGT), the compensated neutron tool (CNT), the aluminum activation clay tool, (AACT), and the gamma-ray spectrometry tool (GST; Fig. 1) (GLT, NGT, CNT, AACT, and GST are trademarks of Schlumberger). The NGT tool is located at the top of the tool string so that it can measure the naturally occurring radionuclides-thorium, uranium, and potassiumbefore the formation is activated by the nuclear sources mounted on other following tools. The compensated neutron tool located below the NGT carries a low-energy neutron californium $\left(\mathrm{Cf}^{252}\right)$ source which activates the aluminum atoms in the formation. The aluminum activation clay tool, a modified natural gamma-ray tool which follows the $\mathrm{Cf}^{252}$ source, measures the activated gamma rays in the formation. By combining this measurement with the previous NGT measurement, background radiation is subtracted out and a reading of formation aluminum (Al) is obtained (Scott and Smith, 1973). Finally, the gamma-ray spectrometry tool, located at the bottom of the tool string, uses a pulsed neutron generator to bombard the borehole, and a detector to measure the spectrum of capture gamma rays generated by neutron capture reactions. Because each of the elements in the formation is characterized by a unique spectral signature, it is possible to derive the contribution (or yield) of the major elements silicon $(\mathrm{Si})$, iron $(\mathrm{Fe})$, calcium $(\mathrm{Ca})$, titanium $(\mathrm{Ti})$, sulfur $(\mathrm{S})$, gadolinium $(\mathrm{Gd})$, and potassium $(\mathrm{K})$ from the measured spectrum. The gamma-ray spectrometry tool also measures hydrogen 


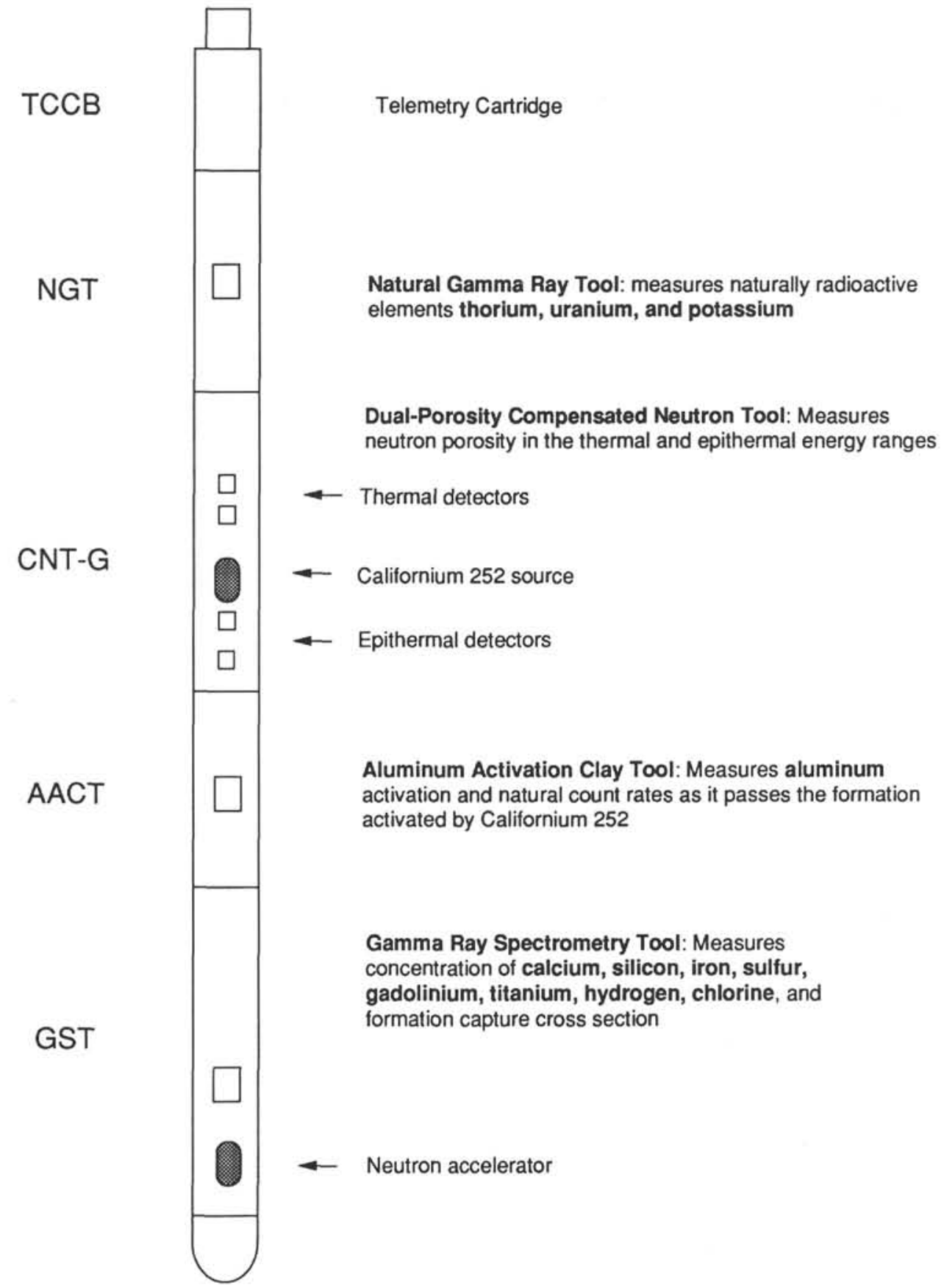

Figure 1. The geochemical tool string as it is run for ODP and the elements measured by each tool.

(H) and chlorine $(\mathrm{Cl})$, but these elements are not used in determining the rock geochemistry.

The only major elements not measured by the geochemical tool string are magnesium $(\mathrm{Mg})$ and sodium $(\mathrm{Na})$. The neutron-capture cross-sections of these elements are too small to be detected by the gamma-ray spectrometry tool. An estimate of their abundances can be made using the photoelectric factor (PEF) from the lithodensity tool when it is run open hole.

\section{PROCESSING OF GEOCHEMICAL LOG DATA}

The well log data from the Schlumberger tools are transmitted digitally up a wireline, and are recorded and processed aboard the JOIDES Resolution in the Schlumberger Cyber Service Unit (CSU). The results from the CSU are made available as "field logs" for initial interpretation while at sea. Subsequent reprocessing is necessary to further correct the data for hole size changes, the effects of fluids added to the well, and variations in logging speed. Processing of the spectrometry data is required in order to transform the relative elemental yields into oxide weight fractions.

The processing is done using a set of log interpretation programs written by Schlumberger. The processing steps are summarized below.

1. Reconstruction of 10 relative elemental yields from recorded spectral data.

The first program uses a least-squares method to compare the measured spectra from the geochemical spectrometry tool 
with a series of standard spectra to determine the relative contribution (or yield) of each element. Whereas only six elemental standards are used to produce the yields at sea, during processing at Lamont-Doherty three additional standards (Ti, Gd, K) are utilized. Although these three elements often occur in very low concentrations in the formation, they can make a large contribution to the measured spectra because of their large neutron-capture cross-sections. The capture crosssection of Gd, for instance, is 49,000 barns $\left(10^{-28} \mathrm{~m}^{2}\right)$; that of $\mathrm{Si}$ is 0.16 barns (Hertzog et al., 1987). Therefore, Gd, although occurring in very small abundances in the formation, must be included when calculating a best fit between the measured and the standard spectra. This best-fit analysis gives $\mathrm{Si}, \mathrm{Ca}, \mathrm{Fe}, \mathrm{Ti}$, $\mathrm{Gd}, \mathrm{S}, \mathrm{H}, \mathrm{Cl}$, and $\mathrm{K}$ as final yields. Before any further manipulation of the yields is done, a 10-point smoothing filter is applied to reduce the amplitude of noise in the data. The iron yield is also corrected for effects of the steel in the drill pipe and the bottom-hole assembly (BHA) by applying an appropriate offset (see the logging section of the Initial Reports, Haq, von Rad, O'Connell, et al., 1990).

\section{Calculation of total radioactivity and $T h, U$, and $K$ concentration.}

The second routine estimates the total gamma radiation, along with the concentrations of $\mathrm{Th}, \mathrm{U}$, and $\mathrm{K}$, using the counts in five spectral windows from the natural gamma-ray tool (Lock and Hoyer, 1971). Again, this is very similar to shipboard processing. One of the main differences, however, is the use of a caliper curve to correct for borehole size changes. A second difference is the complexity of filtering. Because statistical errors in the logs often create erroneous negative readings and anti-correlations (especially between Th and U), a Kalman-type filter (Ruckenbusch, 1983) is applied to reduce these effects. A slightly more sophisticated version of the Kalman filter is available for shore-based processing. The shore-based program also allows for an estimate of potassium from the drilling mud in the hole to be calculated and corrected for. This $\mathrm{K}$ correction is particularly useful in ODP wells where $\mathrm{KCl}$ is typically added to the drilling mud. The outputs of this program are $\mathrm{K}$ (wet weight percent, or wt\%), $\mathrm{U}$ $(\mathrm{ppm})$, and Th (ppm), along with a total gamma-ray curve and a computed gamma-ray curve (Th $+\mathrm{K})$.

\section{Calculation of Al concentration.}

The third routine calculates $\mathrm{Al}$ using four energy windows from the aluminum activation clay tool, while simultaneously correcting for borehole fluid neutron-capture cross-section, formation neutron-capture cross-section, formation slowing-down length, and borehole size. Porosity and density curves were input from core data from Holes $761 \mathrm{C}$ and $764 \mathrm{~B}$, and from the lithodensity string in Hole $762 \mathrm{C}$; these curves are used to convert $\mathrm{Al}$ and $\mathrm{K}$ to dry wt\%. A correction is also made for the $\mathrm{Si}$ in the formation, which can become activated by the $\mathrm{Cf}^{252}$ source, causing a reaction which produces the aluminum isotope $\mathrm{Al}^{28}$. Because this silicon reaction creates a direct interference with the aluminum calculation (Hertzog et al., 1987), the program uses the silicon yield from the gamma-ray spectrometry tool to determine the silicon background correction. The program outputs dry weight percent (wt\%) of $\mathrm{Al}$ and $\mathrm{K}$, which are used in the normalization process for calculating the remaining elements.

\section{Photoelectric factor corrections.}

In the fourth routine, a photoelectric factor (PEF) curve, which is used in the calculation of $\mathrm{Mg}+\mathrm{Na}$, is corrected for tool standoff from the borehole wall and then converted to a dry wt\% reading. This was done for Hole $762 \mathrm{C}$, the only well in which the lithodensity tool (which gives PEF) was run
Table 1. Oxide factors used to normalize elements to $100 \%$ and convert elements to oxides.

\begin{tabular}{clc}
\hline Element & Oxide/carbonate & Conversion factor \\
\hline $\mathrm{Si}$ & $\mathrm{SiO}_{2}$ & 2.139 \\
$\mathrm{Ca}$ & $\mathrm{CaCO}_{3}$ & 2.497 \\
& $\mathrm{CaO}$ & 1.399 \\
$\mathrm{Fe}$ & $\mathrm{FeO}^{*}$ (total iron) & 1.358 \\
$\mathrm{~K}$ & $\mathrm{~K}_{2} \mathrm{O}$ & 1.205 \\
$\mathrm{Ti}$ & $\mathrm{TiO}_{2}$ & 1.668 \\
$\mathrm{Al}$ & $\mathrm{Al}_{2} \mathrm{O}_{3}$ & 1.899 \\
$\mathrm{Mg}$ & $\mathrm{MgO}^{2}$ & 1.658 \\
\hline
\end{tabular}

open-hole. This calculation, however, estimated zero value curves for this well, perhaps due to low $\mathrm{Mg}$ and $\mathrm{Na}$ values.

\section{Normalization of aluminum and potassium with elemental yields to calculate the elemental weight fractions.}

The next routine takes the dry wt\% of $\mathrm{Al}$ and $\mathrm{K}$ and normalizes them with the reconstructed yields to obtain dry wt\% of all the measured elements using the relationship:

$$
W t_{i}=F Y_{i} / S_{i}
$$

where $W t_{i}$ is the absolute elemental concentration, $F$ is the normalization factor, $Y_{i}$ is the relative elemental yield, and $S_{i}$ is the tool spectral sensitivity. The normalization factor, $F$, is a calibration factor determined at each depth to account for the presence of carbon (C) and oxygen (O) associated with each element. Because the sum of oxides in a rock is $100 \%, F$ is given by

$$
F\left(\Sigma X_{i} Y_{i} / S_{i}\right)+X_{K} W t_{K}+X_{A l} W t_{A l}=100 \%
$$

where $X_{i}$ is the dry wt $\%$ of the oxide form of element $i, Y_{i}$ is the fraction of spectra attributed to element $i, S_{i}$ is the sensitivity factor, $X_{K}$ is the dry wt $\%$ of K oxide divided by the dry wt $\%$ of $\mathrm{K}, W t_{K}$ is the dry wt $\%$ of $\mathrm{K}, X_{A l}$ is the dry wt\% of Al oxide divided by the dry wt $\%$ of $\mathrm{Al}$, and $W t_{A l}$ is the dry wt $\%$ of $\mathrm{Al}$. The sensitivity factor, $S_{i}$, is a tool constant measured in the laboratory, which depends on the capture cross-section of each element measured by the geochemical tool (Hertzog et al., 1987).

The routine next calculates the sum $(\mathrm{Mg}+\mathrm{Na})$ if the lithodensity measurements are available. This pair of elements can be estimated (when they occur in significant quantities) by comparing the measured PEF from the lithodensity tool with a calculated PEF curve. Because the PEF of each element is known, a photoelectric factor curve can be calculated assuming no $\mathrm{Mg}$ and $\mathrm{Na}$ in the formation. The difference between this calculated PEF curve and the measured PEF log is assumed to be due to $\mathrm{Mg}$ and $\mathrm{Na}$ in the formation (Hertzog et al., 1987).

\section{Calculation of oxide percentages.}

The sixth and last routine multiplies the percentage of each element by the oxide or carbonate factor associated with each element. These factors are listed in Table 1.

\section{COMPARISON OF LITHOLOGY FROM CORES AND GEOCHEMICAL WELL LOGS}

\section{Site 761}

Natural gamma-ray logs were recorded on both the incomplete open-hole pass of the seismic stratigraphic logging run and the through-pipe pass of the geochemical logging run. The natural gamma-ray logs from the geochemical logging run are presented here, as this run contains the longer interval of data (Fig. 2). Corrections were made for attenuation by the drill 


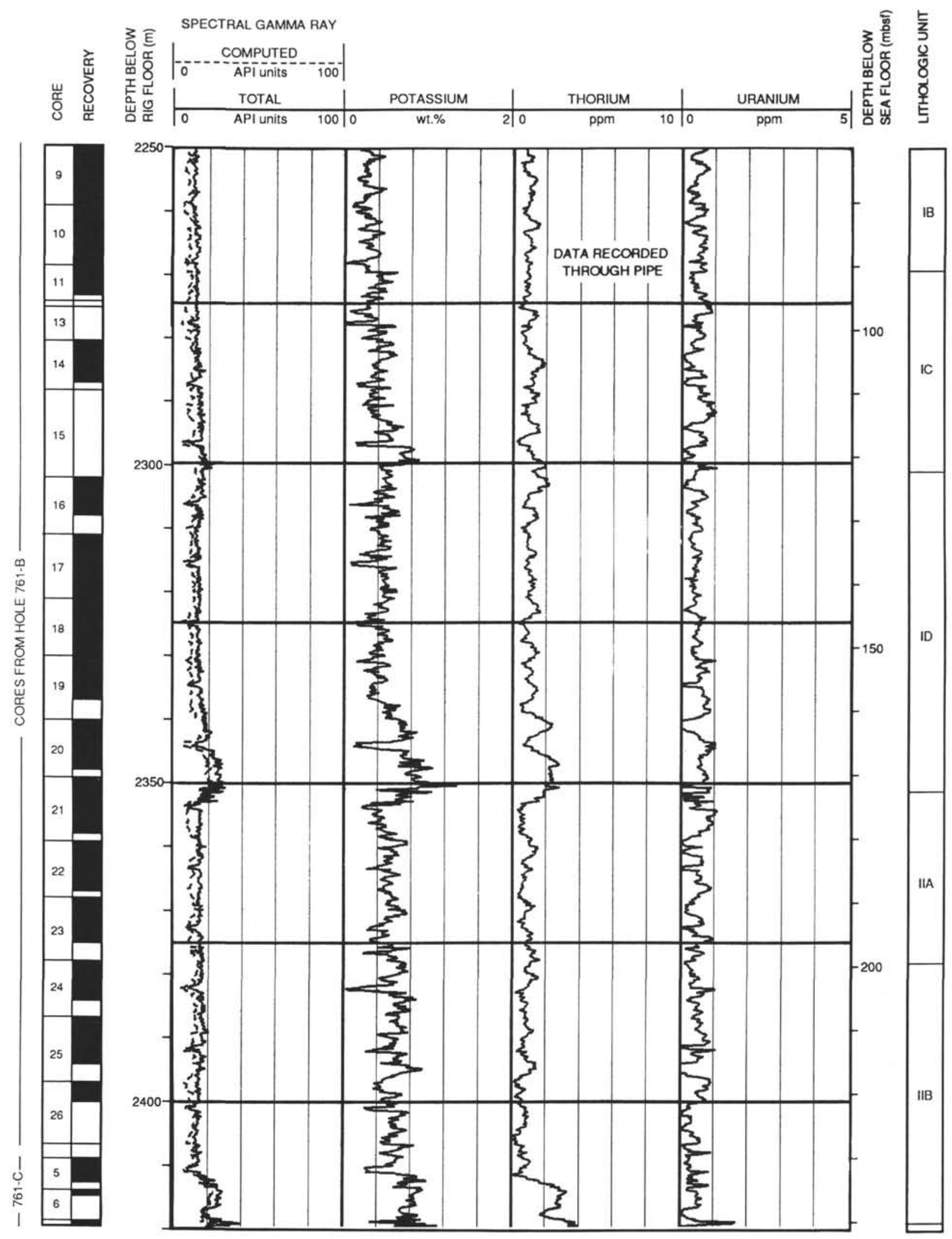

Figure 2. Processed natural gamma-ray curves from Holes 761B and 761C. Legend of lithologic units: Unit IB-nannofossil ooze; Unit IC - nannofossil ooze with foraminifers and chert; Unit ID—nannofossil chalk with foraminifers; Unit IIA-nannofossil chalk; Unit IIB —nannofossil chalk with foraminifers; Unit IIC—nannofossil chalk with bentonite/smectite layers; Unit III—sandstone; Unit IV-limestone; Unit VA-limestone and calcareous claystone; Unit VB—claystone and limestone. 


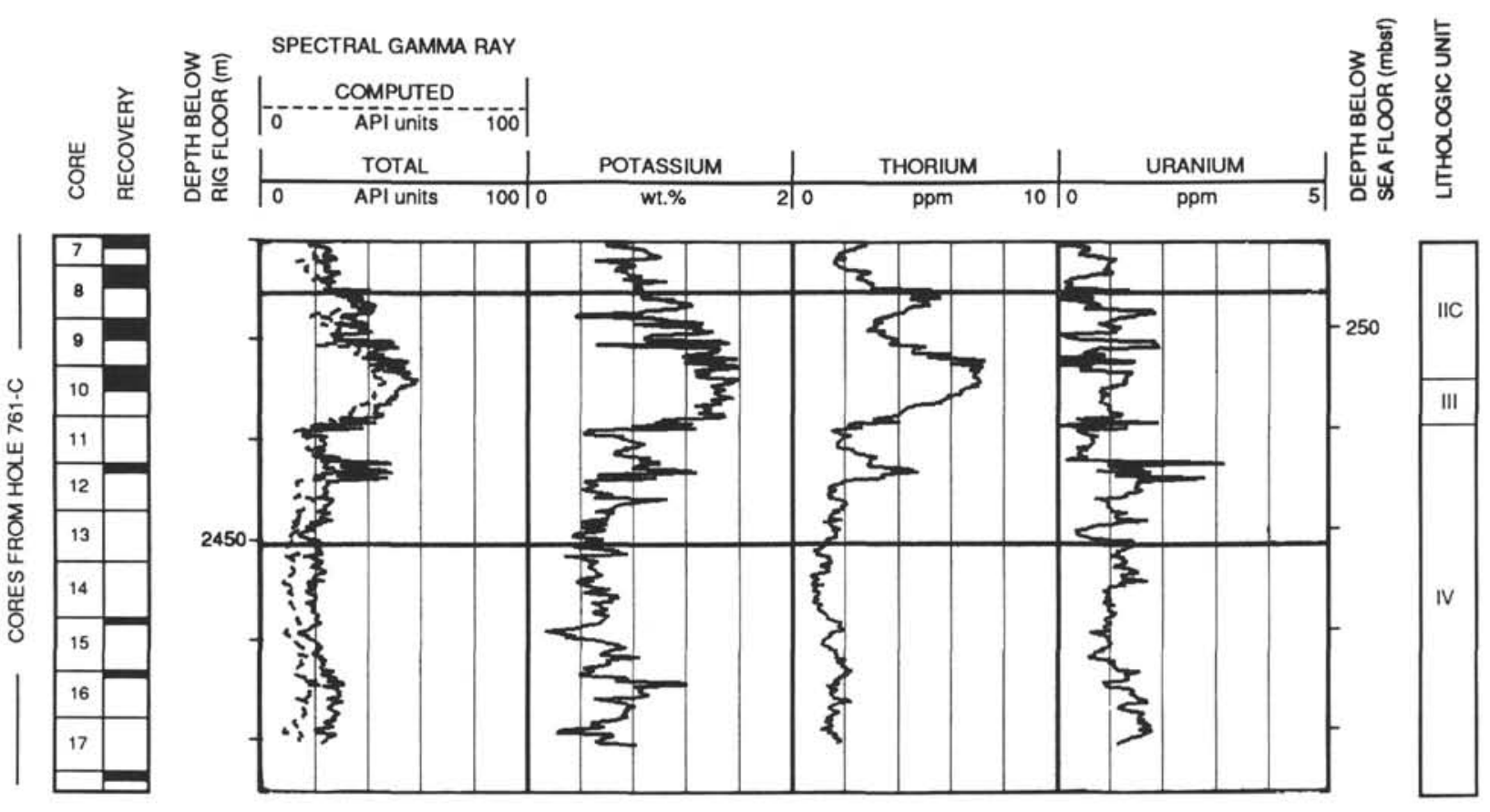

Figure 2 (continued).

pipe and the BHA on the natural gamma-ray curves. The BHA section from 292 to 410 mbsf is not presented due to the extremely poor quality of the data in this section.

The computed oxide weight fraction and calcium carbonate logs are displayed in Figure 3. Corrections were applied to the iron yield to account for iron in the pipe and BHA. Calcium carbonate analyses of core data are displayed alongside the log-derived calcium carbonate curve. The two measurements show an overall correlation; however, the log values are lower and have a higher variability. A few major discrepancies exist between the log and core measurements where discrete samples of chert (Samples 122-761B-11X-1, 80-83 cm, and 122761B-23X-4, 73-75 cm), sandstone (Samples 122-761C-9R-1, $145-147 \mathrm{~cm}$, and 122-761C-10R-2, 37-39 cm), and claystone (Samples 122-761C-9R-2, 8-10 cm, and 122-761C-30R-2, 98$100 \mathrm{~cm}$ ) were analyzed from units that otherwise had high calcium carbonate concentrations. The logs were unable to detect these anomalous lithologies ( 1 to $10 \mathrm{~cm}$ thick) because of the low vertical resolution $(50 \mathrm{~cm})$ of the geochemical logging tools.

Lithologic descriptions divide the sediments into five major units (Haq, von Rad, O'Connell, et al., 1990). Units I and II are not distinguished on the logs due to the similar chemical nature of oozes and chalks. Unit III (255-259.5 mbsf), consisting of silty claystone and sandstone, is a transition zone on the logs, varying from relatively high $\mathrm{SiO}_{2}$ and intermediate $\mathrm{CaCO}_{3}$ wt\% at the top of the interval, to low $\mathrm{SiO}_{2}$ and high $\mathrm{CaCO}_{3}$ at the base of the unit. The sandstone and claystone of Unit III, which were not well recovered in the core, appear from the log data to be more extensive than the core data indicate (Fig. 2). High thorium and potassium values are observed from 246 to $260 \mathrm{mbsf}$. Thorium indicates the presence of heavy minerals, whereas potassium is associated with feldspar and mica, which often occur as detrital material in sandstone. Unit IV (259.5-338.3 mbsf) is predominantly white limestone (with minor amounts of grainstone) and mudstone. Even though Unit IV was poorly recovered, the limestone and interbedded grainstone can be readily differentiated on the geochemical logs, par- ticularly using the $\mathrm{CaCO}_{3}$ curve (Fig. 3). Unit V (338.3$411.0 \mathrm{mbsf}$ ) is a sequence of interbedded carbonate mudstone to grainstone and calcareous claystone to silty claystone. The boundary between lithologic Units IV and V is quite distinct on the calcium carbonate and aluminum oxide logs (Fig. 3), and marks a change in the log character from little variation within the limestone interval above, to high variation in Unit $\mathrm{V}$ below.

\section{Site 762}

Natural gamma-ray logs were recorded on each of the three logging passes. The recomputed natural gamma-ray logs displayed in Figure 4 are derived from the seismic stratigraphic logging run, as this pass contained the longest open-hole logging run (902-192 mbsf).

Geochemical logs were recorded open-hole between 502 and 906 mbsf. The calculated oxide and carbonate measurements for Site 762 are displayed in Figure 5. The calcium carbonate concentration from core analysis and the calculated calcium carbonate curve correlate well. The one noteworthy exception is at approximately 865 mbsf (Sample 122-762C$82 \mathrm{X}-2,78-103 \mathrm{~cm})$, where the $\mathrm{CaCO}_{3}$ analysis was made on a 25 -cm-thick limestone bed interstratified with the silty claystones that dominate the lithology of Unit VI.

The natural gamma-ray logs recorded over lithologic Units II and III (192.0-554.8 mbsf) show only small amplitude variation in the nannofossil chalks (Fig. 4). Potassium and thorium values increase near the bottom of Unit III, indicating an increase in detrital material. Both radioactive elements decrease abruptly at the base of Subunit IIIB (Cretaceous/ Tertiary boundary). Within Unit IV (554.8-838.5 mbsf), the gamma-ray log values are low except in Subunits IVD and IVE, where the gradual increase in thorium and potassium indicates a greater component of clay and detrital material in the nannofossil chalk. This is supported by core analysis, which indicates that calcium carbonate concentration drops as low as $51 \%$ in some of the darker beds. The top of Unit V ( $835.5-848.5 \mathrm{mbsf}$ ) is quite distinct on both the natural gamma-ray (Fig. 4) and oxide curves (Fig. 5), marking the change 


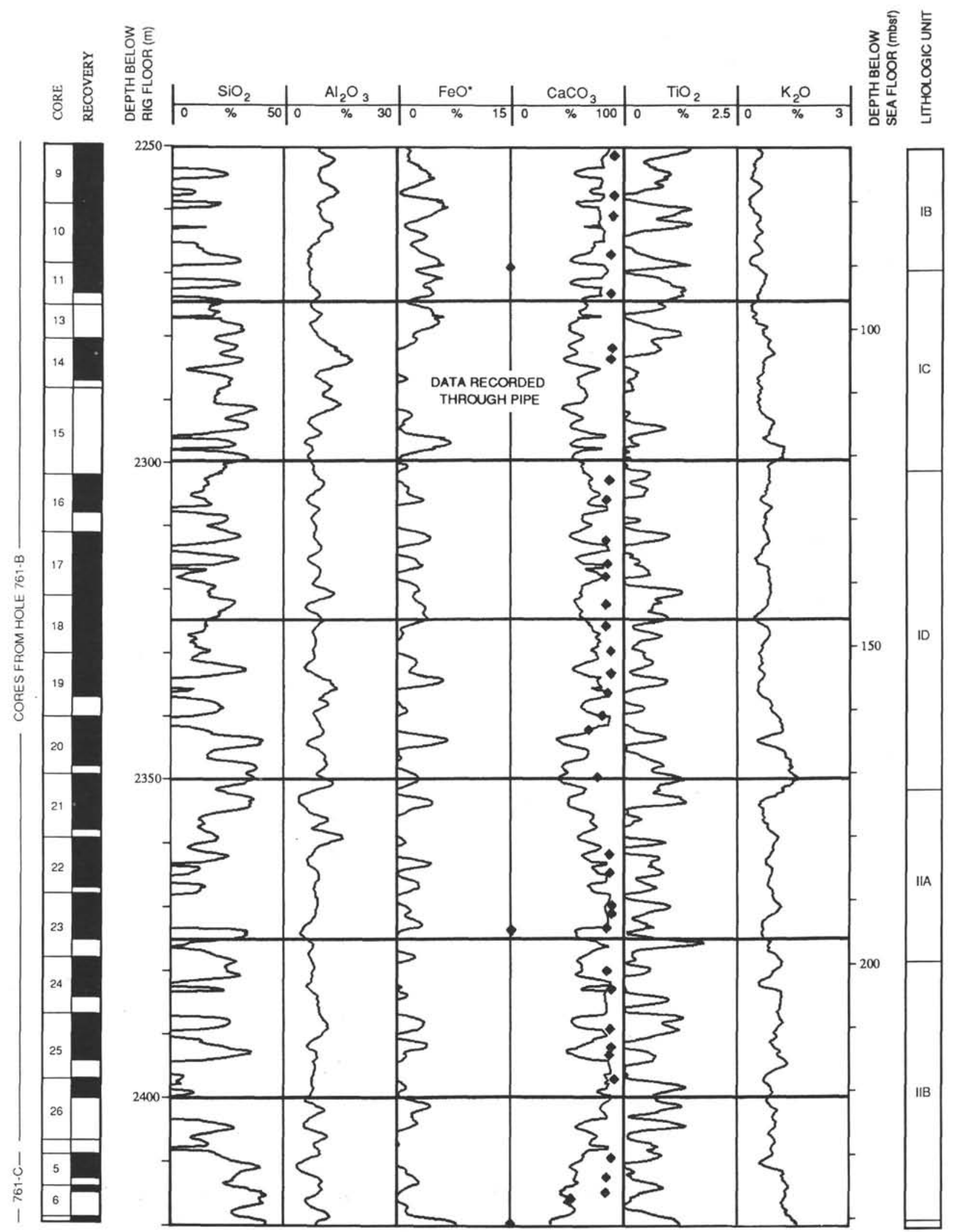

Figure 3. Oxide weight fractions and calcium carbonate at Holes 761B and 761C. Results of calcium carbonate analyses on core samples are shown as diamonds. 


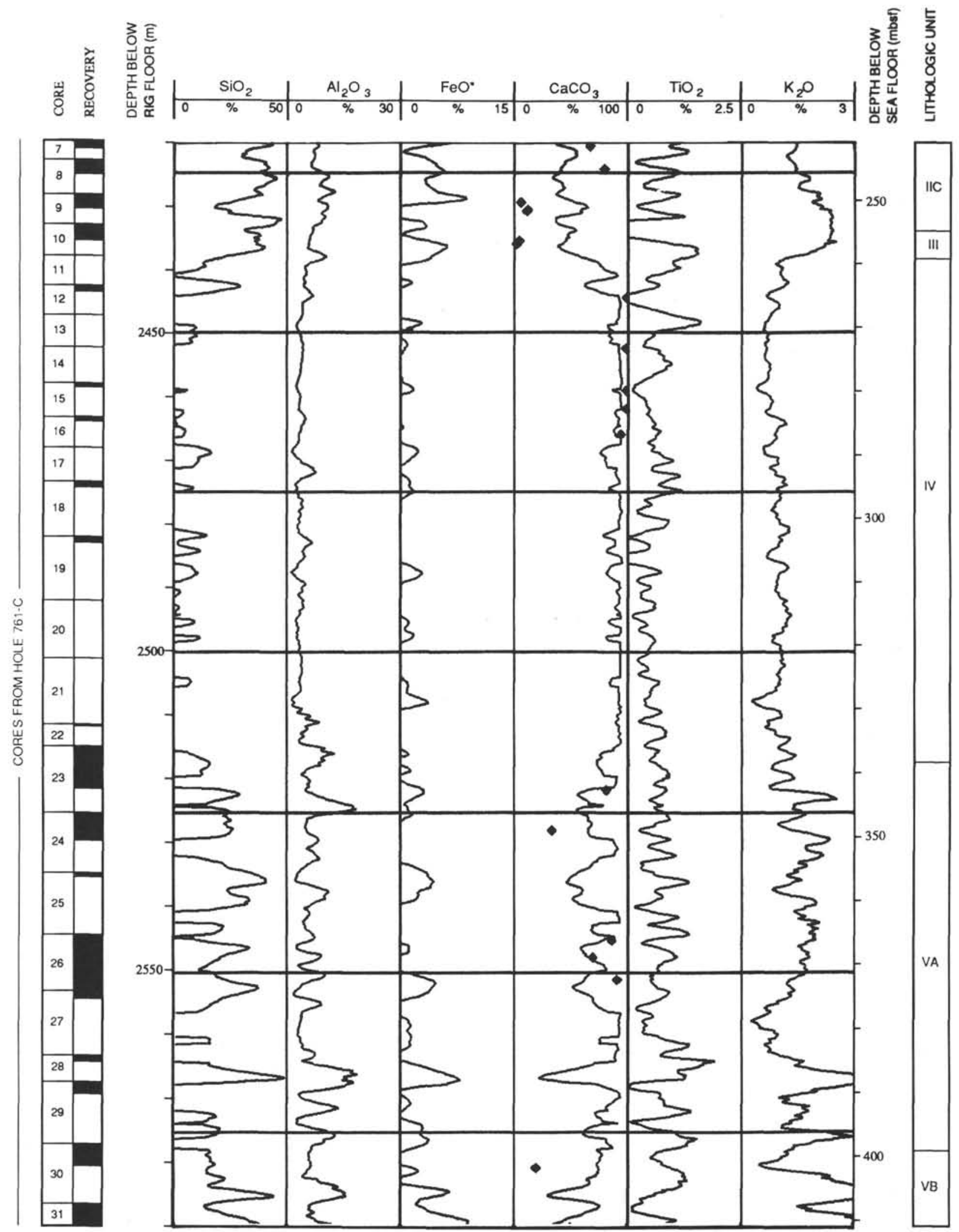

Figure 3 (continued). 

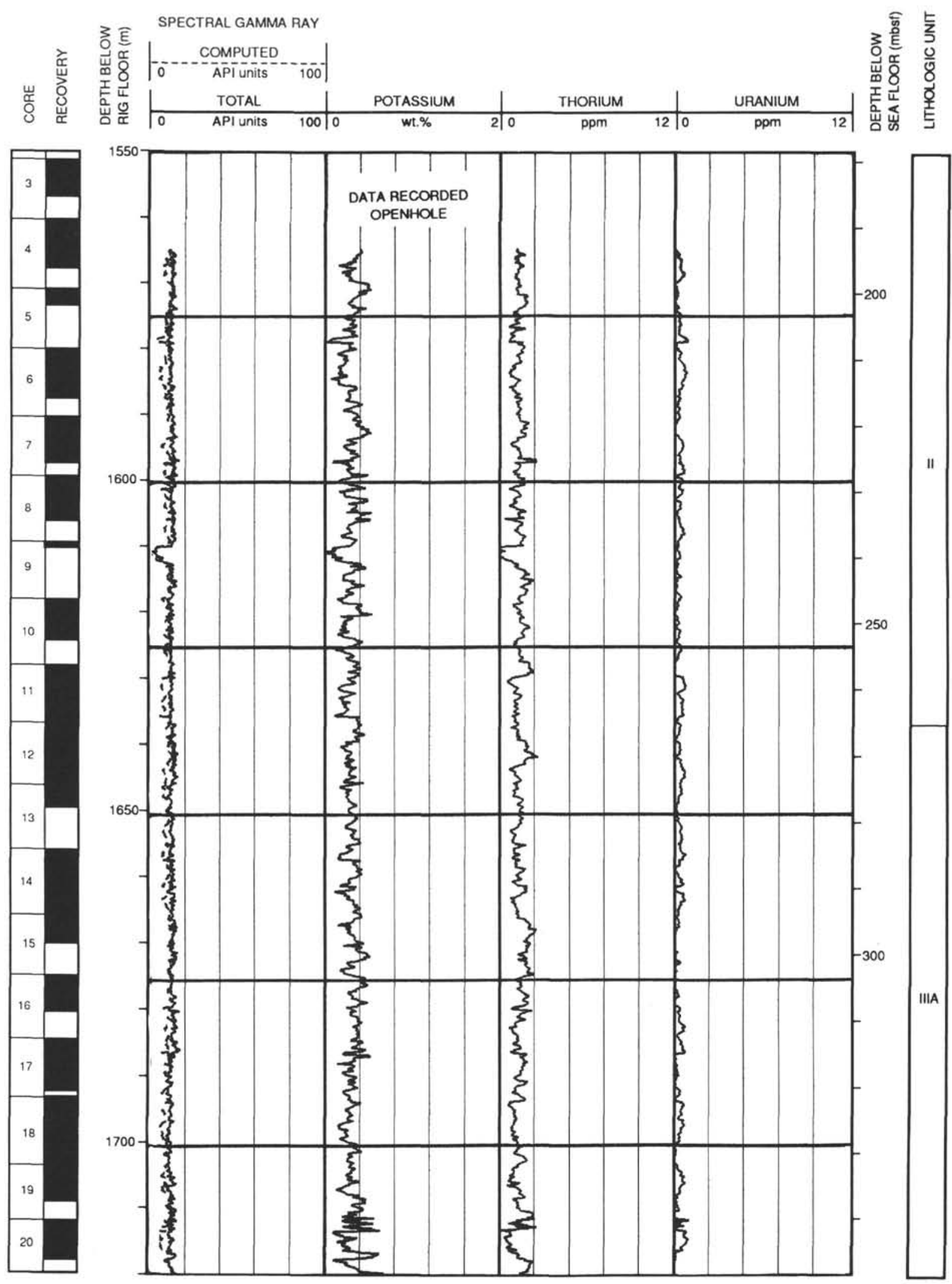

Figure 4. Processed natural gamma-ray curves from Hole 762C. Legend of lithologic units: Unit IIIB-nannofossil chalk; Unit IVA-nannofossil chalk and clayey nannofossil chalk; Unit IVB-nannofossil chalk with foraminifers and nannofossil claystone; Unit IVD—nannofossil chalk with foraminifers and clayey nannofossil chalk; Unit IVE-nannofossil calcareous chalk and clayey nannofossil chalk; Unit V-calcareous claystone; Unit VI-silty claystone and clayey siltstone. 

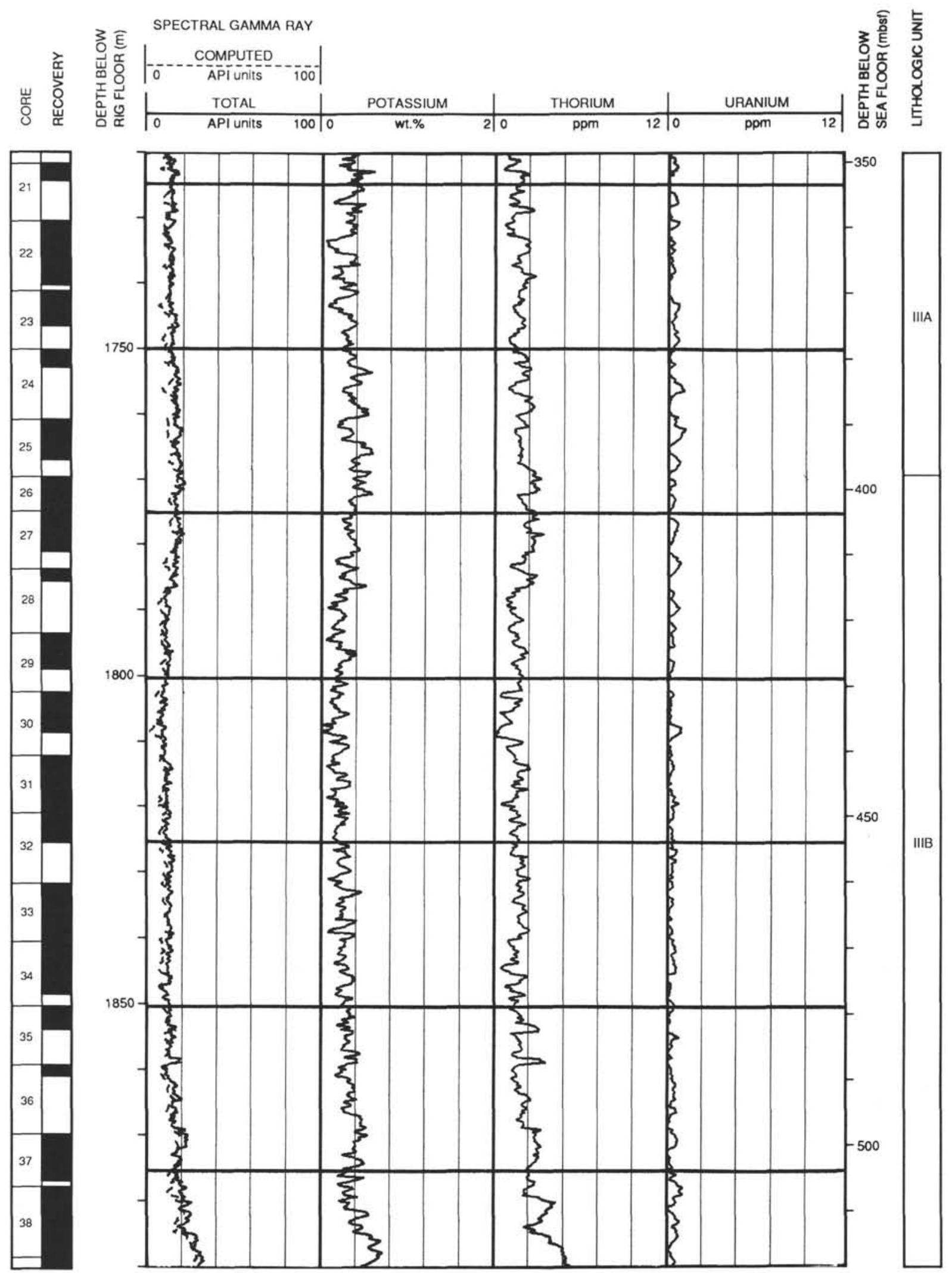

Figure 4 (continued). 

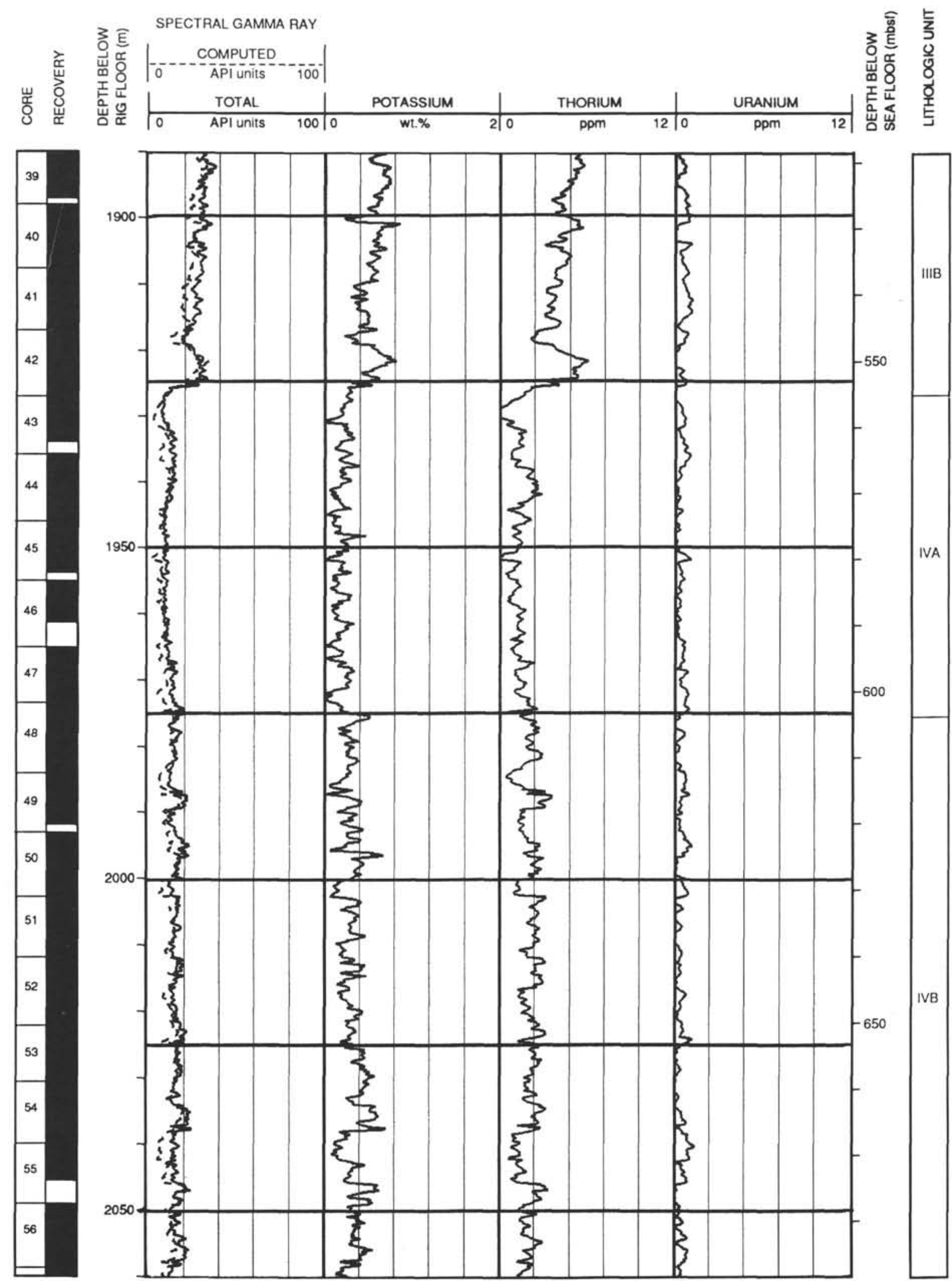

Figure 4 (continued). 

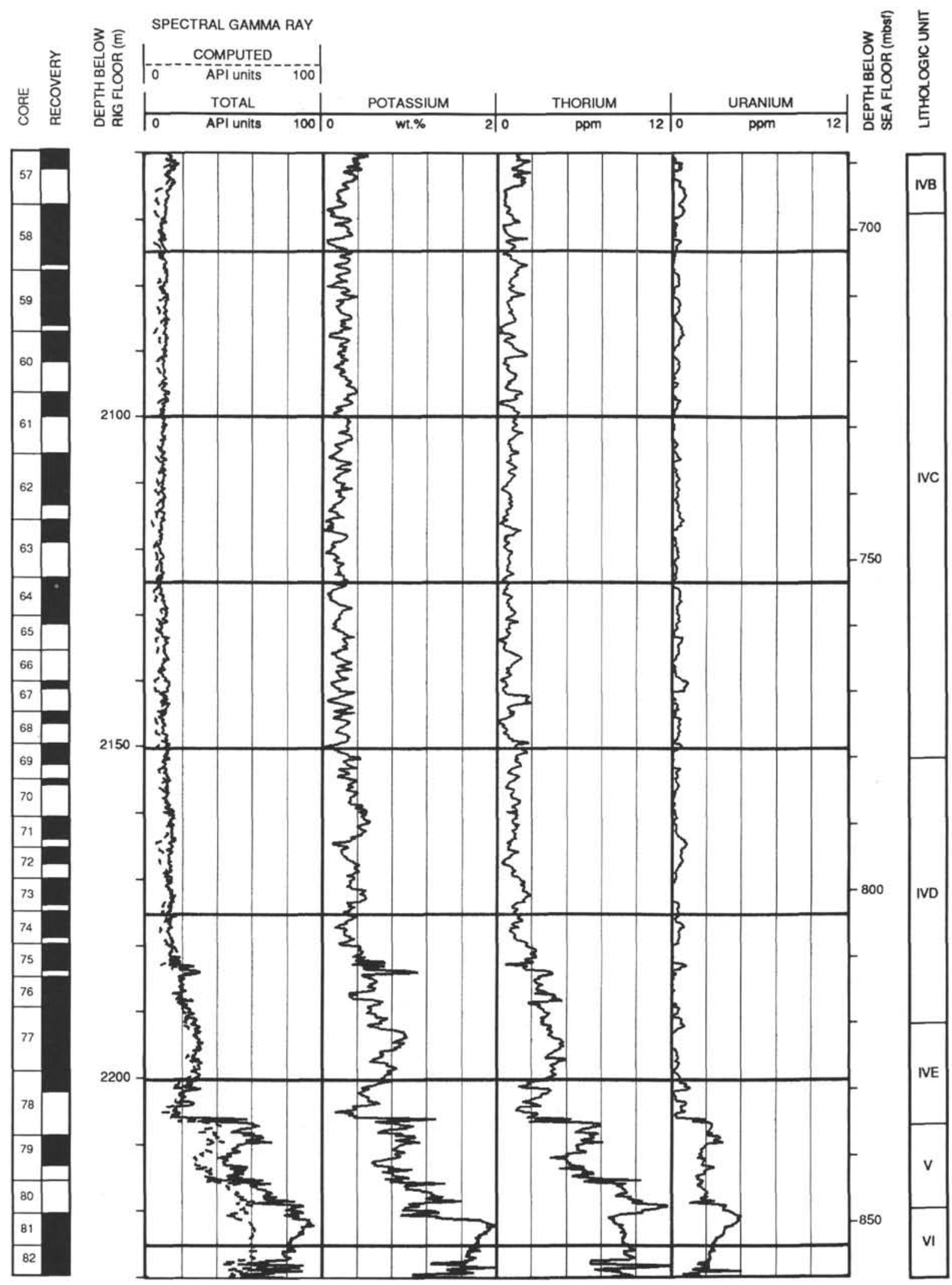

Figure 4 (continued). 

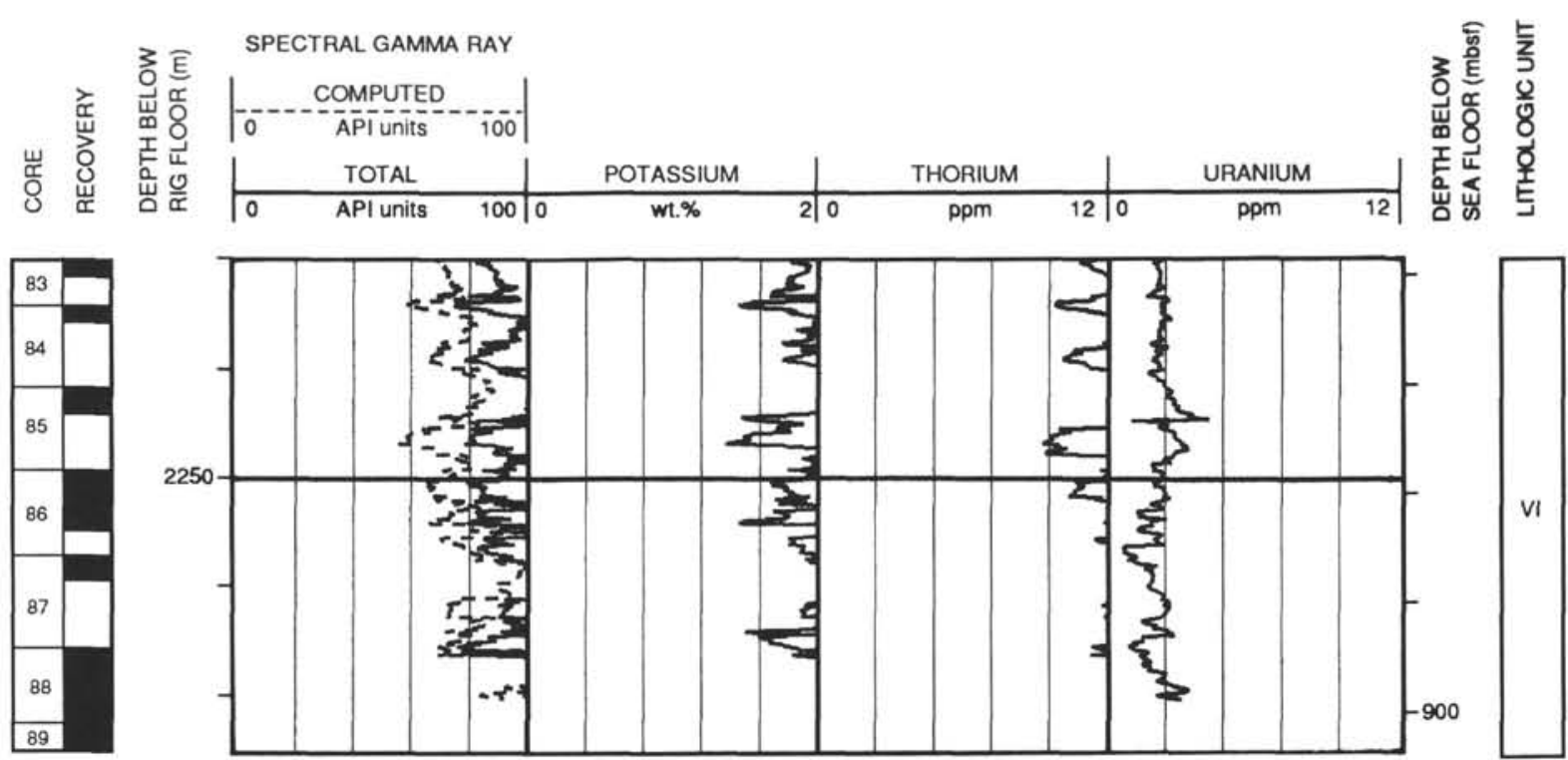

Figure 4 (continued).

from siliciclastic sediments in Unit V to pelagic carbonates in Subunit IVE. The change from Unit V (calcareous claystone) to Unit VI (848.5-902.0 mbsf; silty claystone and clayey siltstone) is seen as a strong baseline shift on the natural gamma-ray curves (Fig. 4) and a somewhat lesser shift on the aluminum and iron oxide curves (Fig. 5).

\section{Site 764}

All $\log$ data at this site were recorded through pipe, and therefore the signal from the formation is more attenuated compared to the open-hole logs of Site 762. The natural gamma-ray logs presented (Fig. 6) come from the geochemical logging run. Corrections have been made to account for pipe attenuation in the natural gamma-ray logs; however, there are some zones in which the pipe became irradiated (marked with asterisks on the logs) due to pipe movement.

The computed oxides along with carbonate core measurements are displayed in Figure 7. Corrections were made to the iron yield to account for iron in the pipe and the BHA. Excellent agreement is seen between the carbonate measurements from core and logs despite the adverse logging conditions in this hole.

Units I, II, and III, consisting of nannofossil oozes and chalks, cannot be differentiated on either the geochemical or natural gamma-ray logs (Fig. 6 and 7). The top of Unit IV (49.6-55.9 mbsf) is marked by a sharp uranium peak and a minor increase in thorium, indicating a thin clay bed at the top of the unit. Core recovery within this interval was approximately $30 \%$. The lithologies recovered range from carbonate mudstone, wackestone, and skeletal packstone to grainstone. The top of Unit V (55.9-72.5 mbsf) appears on the logs at approximately $61.5 \mathrm{mbsf}$ as a pronounced increase on the potassium, thorium, and aluminum oxide curves. The increased clay component in the lithology of Unit V, which consists of calcareous claystones and clayey limestones, is confirmed by these logs.

Unit VI (72.5-280.0 mbsf) is predominantly composed of limestone, with minor amounts of mudstones, laminated claystones, and dolomitic mudstones. Because core recovery was less than $10 \%$ in this interval, subunits of this interval were not identified. Log analysis, however, shows that this unit can possibly be subdivided into three intervals on the basis of $\log$ character. The top subunit ( $84-118 \mathrm{mbsf}$ ) is characterized by high $\mathrm{Th}$ and $\mathrm{FeO}^{*}\left(\mathrm{Fe}_{2} \mathrm{O}_{3}+\mathrm{FeO}\right)$ values and low $\mathrm{SiO}_{2}$ and $\mathrm{Al}_{2} \mathrm{O}_{3}$ values. This suggests that clays are absent and that the high gamma-ray signal is probably due to a heavy mineral concentration. The second subunit (118-200 mbsf) is characterized by a higher aluminum concentration throughout the subunit, and a very low concentration of potassium and uranium in the upper section, gradually increasing toward the bottom of the subunit. The third subunit (200-252 mbsf) is characterized by low clay content (low gamma ray and $\mathrm{Al}_{2} \mathrm{O}_{3}$ ) and high calcium carbonate (Fig. 6 and 7). However, the change in log character at this point is questionable due to the increase in pipe thickness in the BHA at this depth.

\section{CONCLUSIONS}

The reprocessing of geochemical logs described above improves the usefulness of the measurements made in the field by providing quantitative measurements which can be compared to core. When core data is missing, the reprocessed well logs are an invaluable data set from which a representative lithologic column can be derived and geology interpreted.

\section{REFERENCES}

Haq, B. U., von Rad, U., O'Connell, S., et al., 1990. Proc. ODP, Init. Repts., 122: College Station, TX (Ocean Drilling Program).

Hertzog, R., Colson, L., Seeman, B., O'Brien, M., Scott, H., McKeon, D., Wraight, P., Grau, J., Schweitzer, J., and Herron, M., 1987. Geochemical Logging With Spectrometry Tools: Soc. Pet. Eng. Pap., 18:792.

Lock, G. A., and Hoyer, W. A., 1971. Natural gamma-ray spectral logging. Log Analyst, 12:3-9.

Ruckenbusch, G., 1983. A Kalman filtering approach to natural gamma-ray spectroscopy in well logging. IEEE Trans. Auto. Control, 28:372-380.

Scott, H. D., and Smith, M. P., 1973. The aluminum activation log. Log Analyst, 14:3-12.

Date of initial receipt: 2 May 1990

Date of acceptance: 16 November 1990

Ms 122B-188 


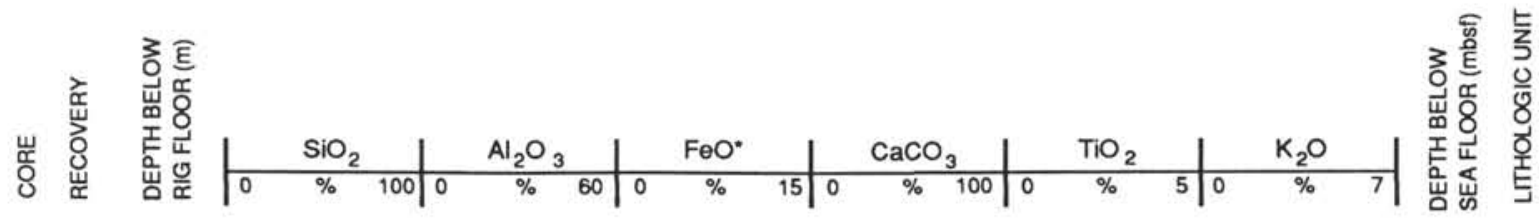

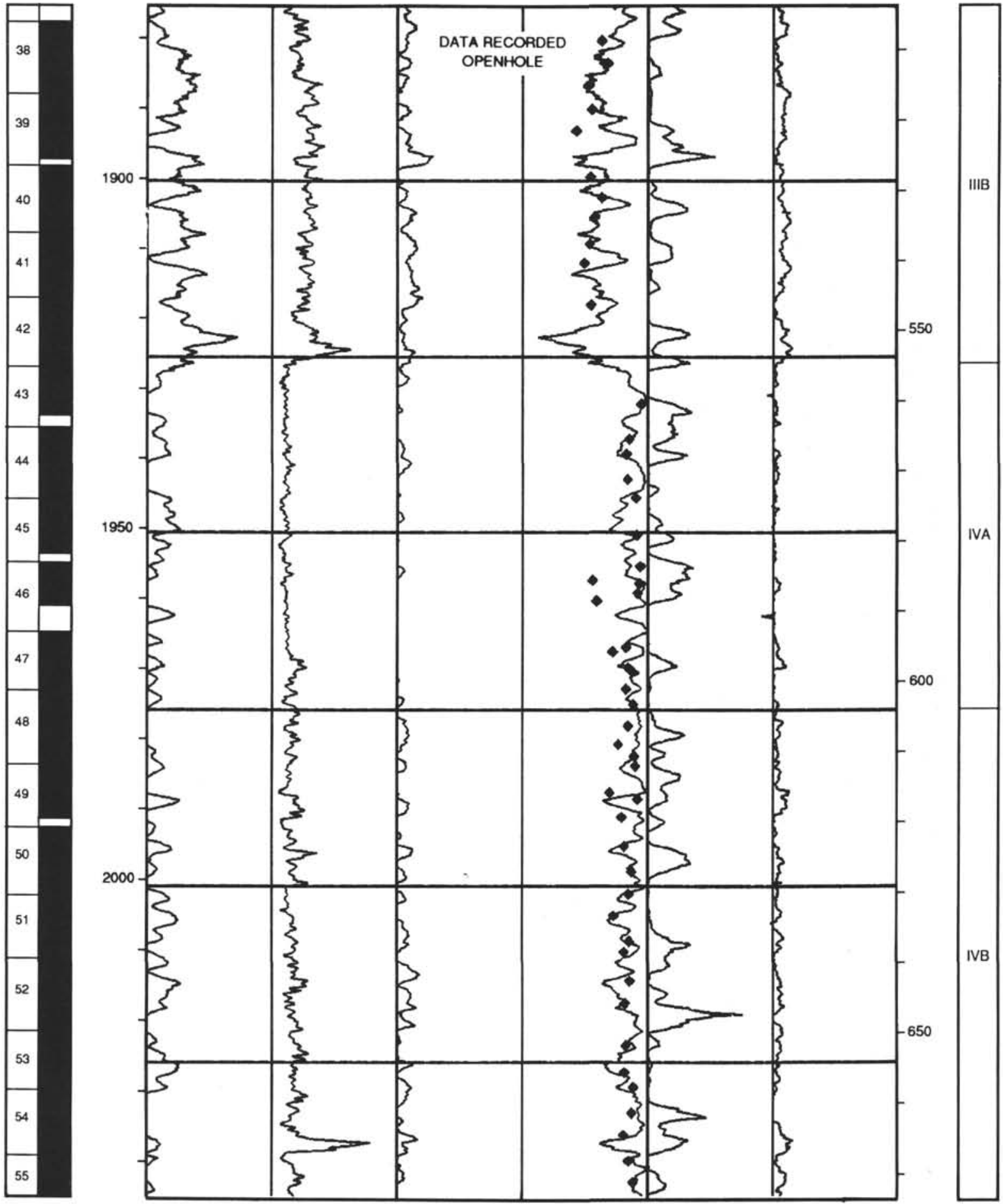

Figure 5. Oxide weight fractions and calcium carbonate at Hole 762C. Results of calcium carbonate analyses on core samples are shown as diamonds. 

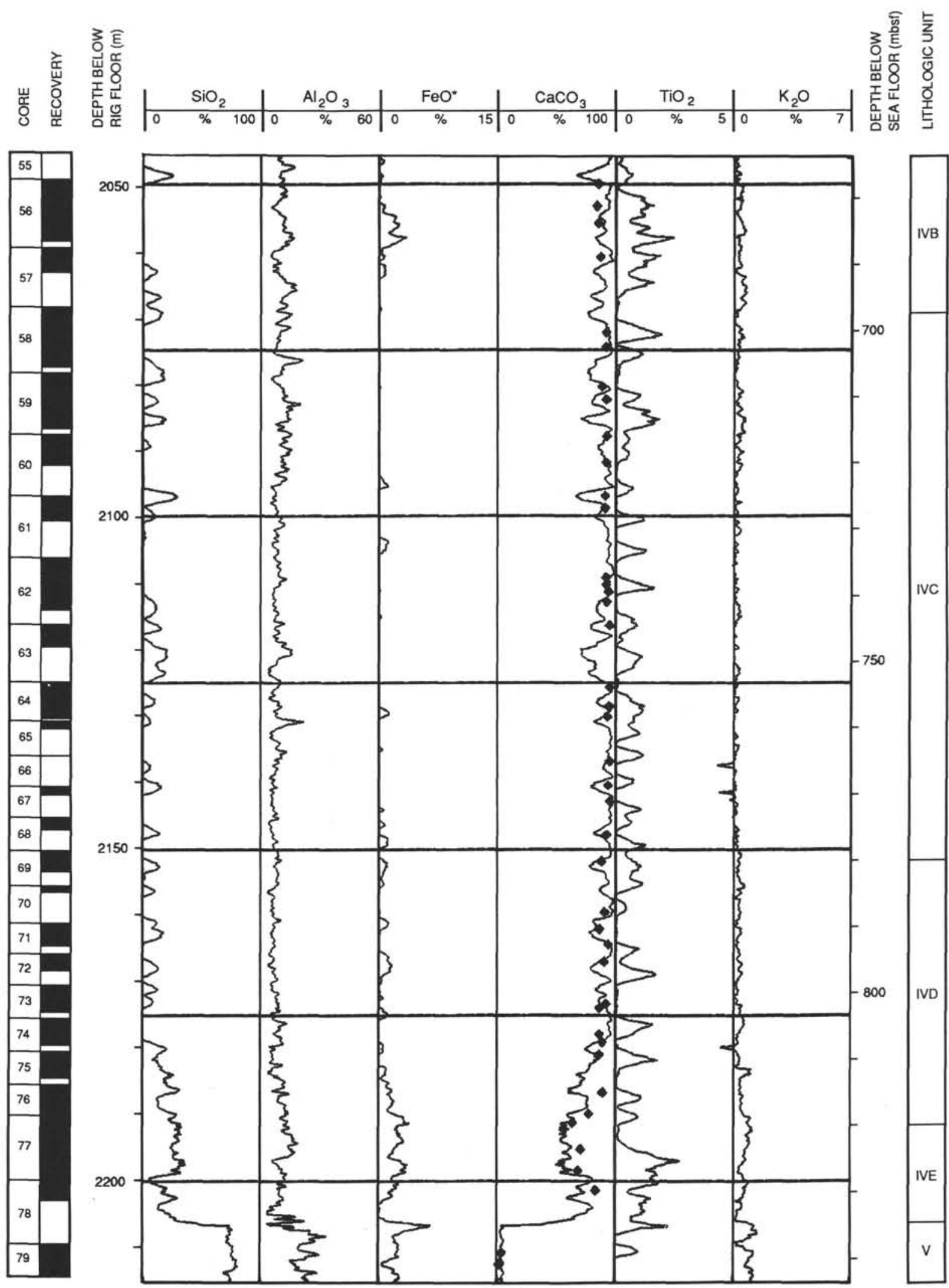

Figure 5 (continued). 

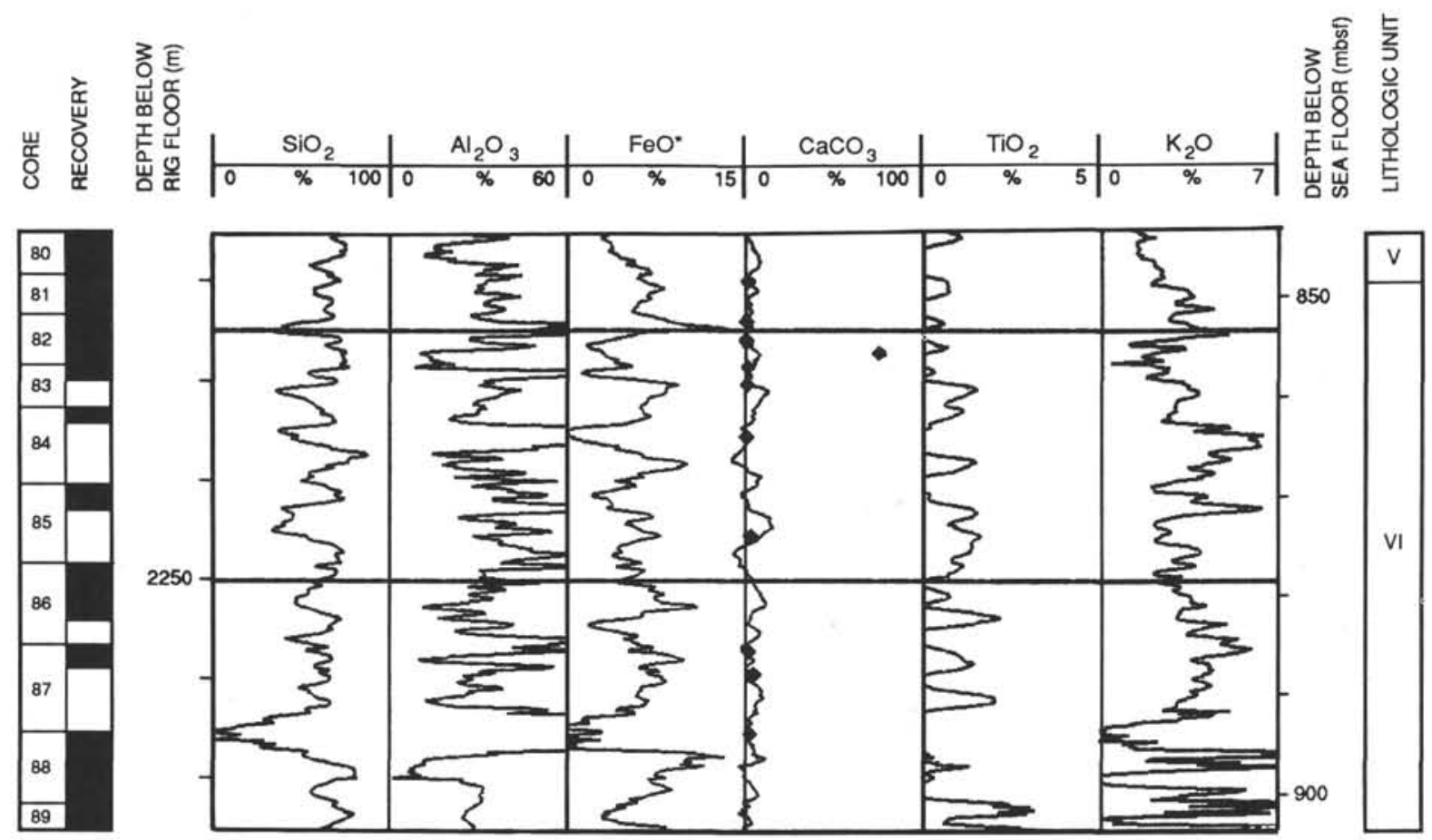

Figure 5 (continued). 


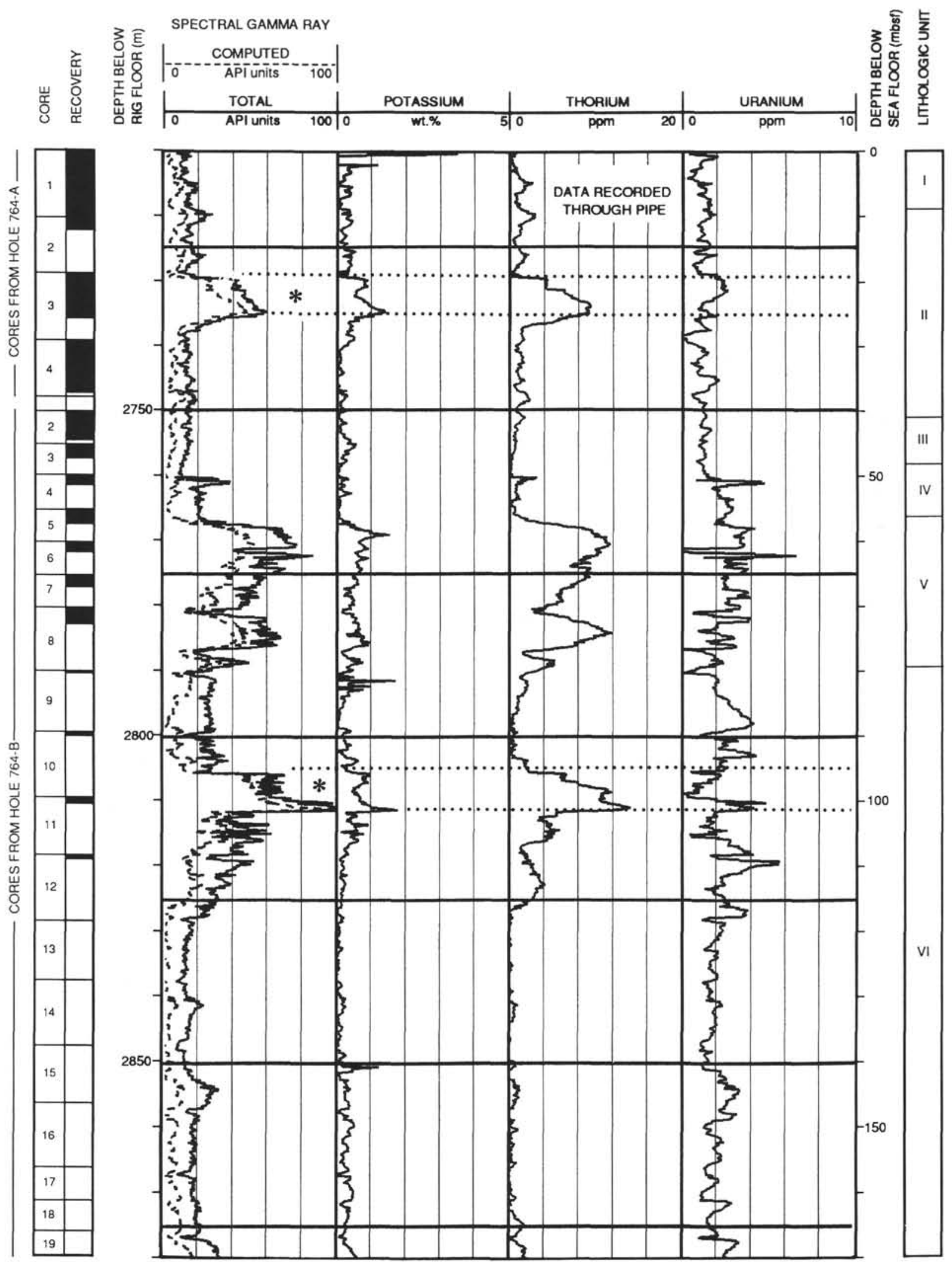

Figure 6. Processed natural gamma-ray curves at Holes 764A and 764B. The log peaks at $24.0-30.5$ mbsf and $100-106$ mbsf (indicated by asterisks) are due to pipe movement and are therefore invalid. Legend of lithologic units: Unit I-foraminifer nannofossil ooze; Unit II-nannofossil ooze with clay and foraminifer nannofossil ooze with clay; Unit III-nannofossil chalk and foraminifer nannofossil chalk; Unit IV-fossiliferous wackestone, packstone, and grainstone; Unit V-limestone and calcareous claystone; Unit VI—boundstone, grainstone, dolomitic claystone, and rudstone. 

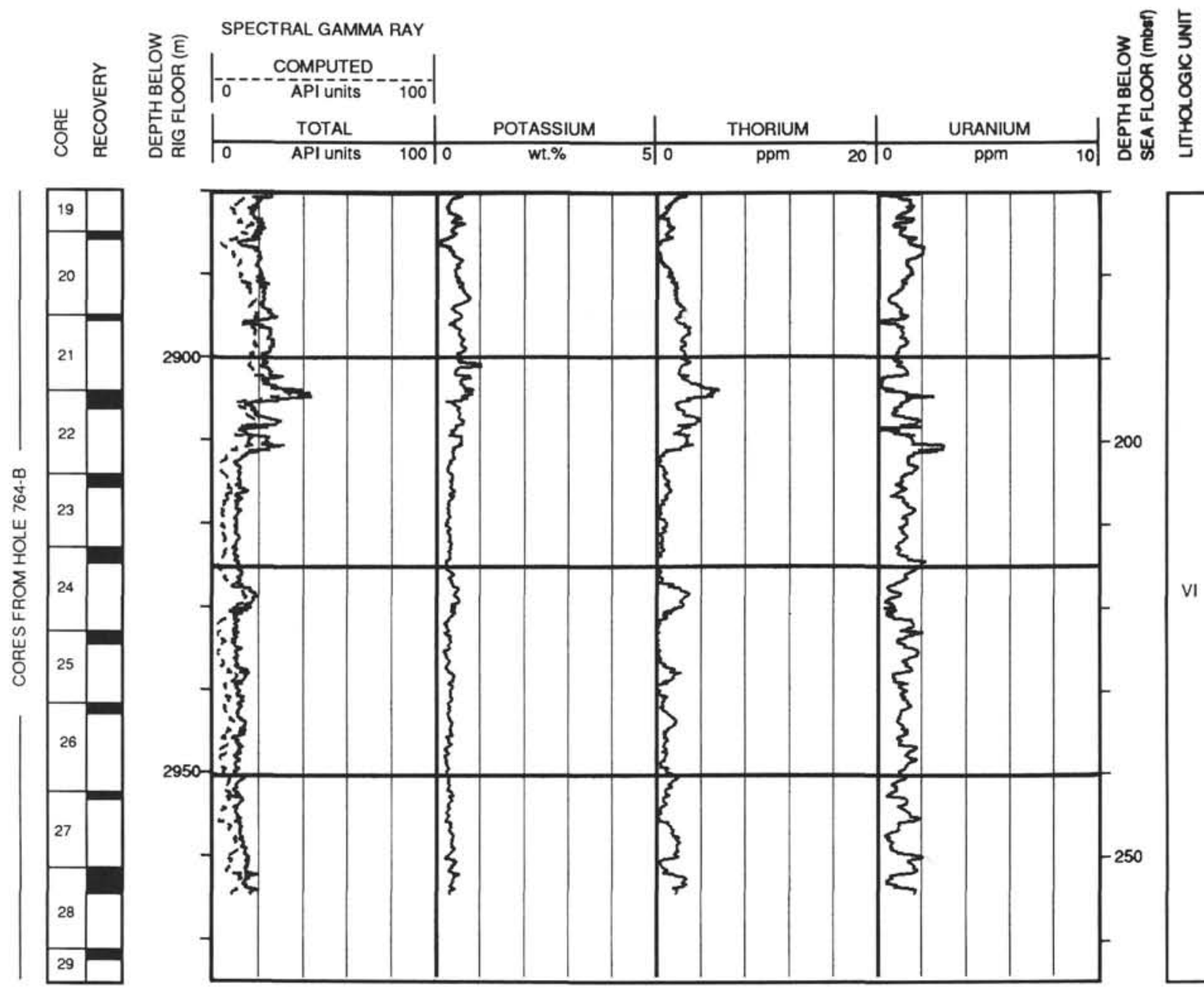

Figure 6 (continued). 


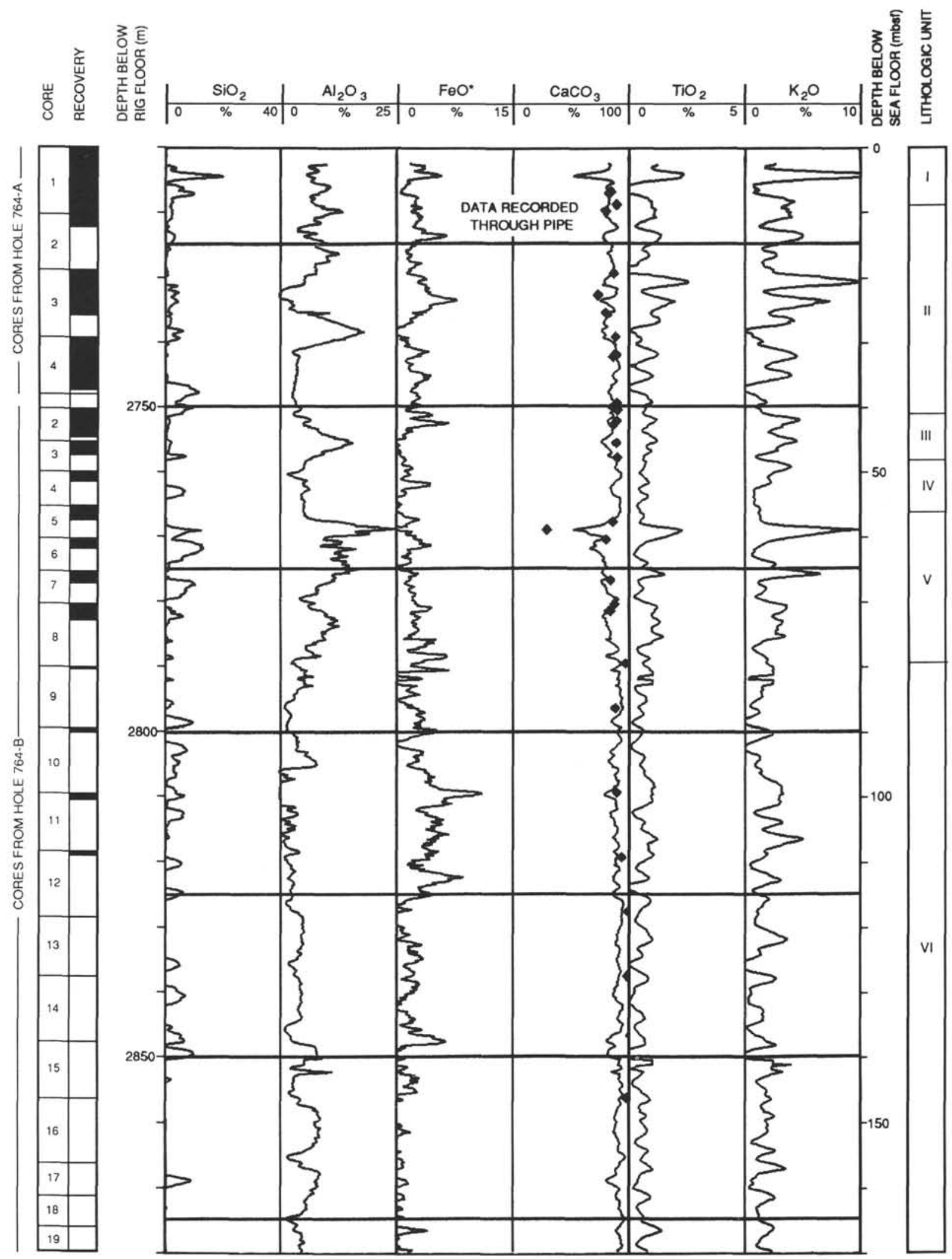

Figure 7. Oxide weight fractions at Holes 764A and 764B. Results of calcium carbonate analyses on core samples are shown as diamonds. 


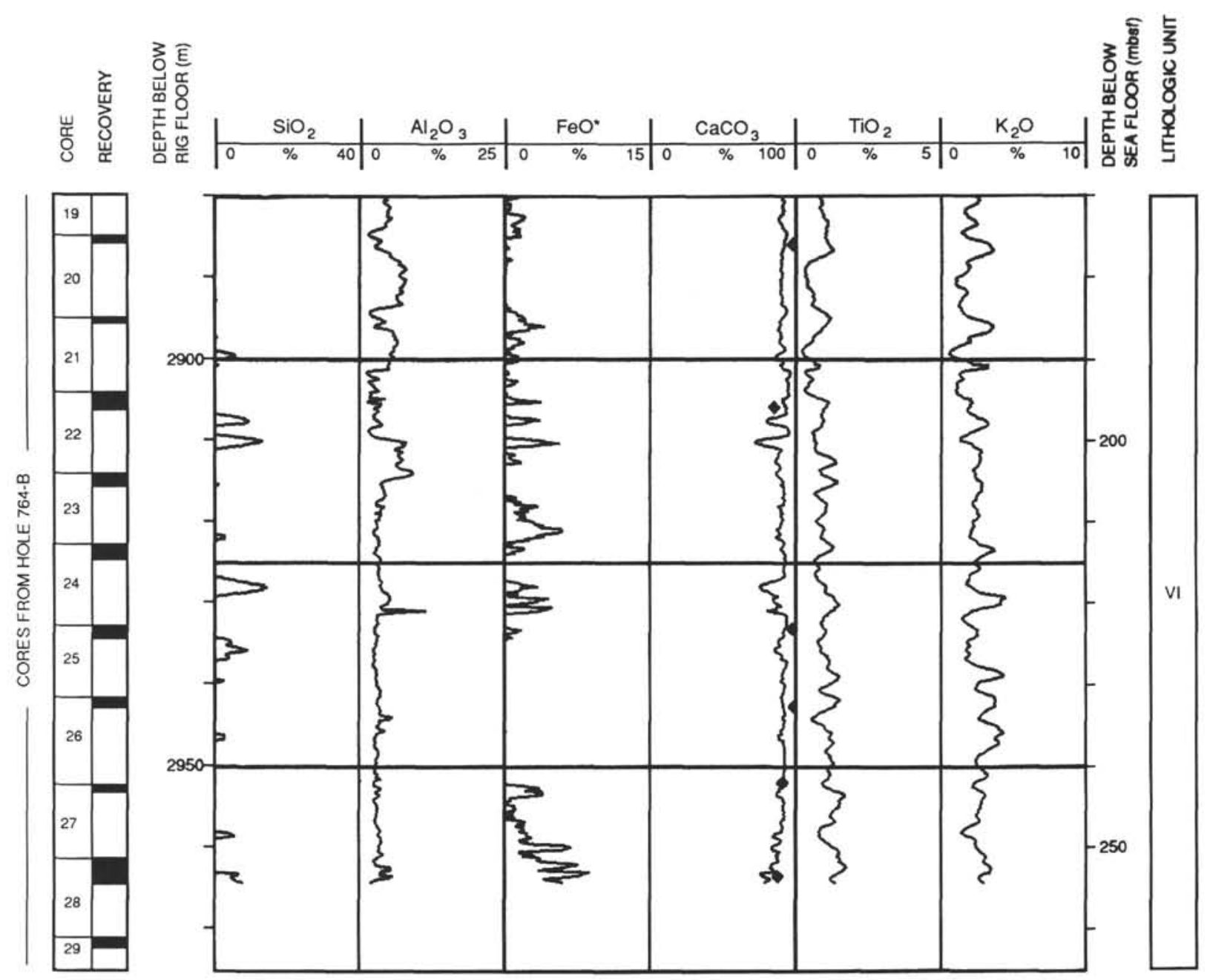

Figure 7 (continued). 